The Agriculturists 12(1): 140-147 (2014) ISSN 2304-7321 (Online), ISSN 1729-5211 (Print)

A Scientific Journal of Krishi Foundation

Indexed Journal

\title{
A Study on the Different Forms of Potassium in the Low Ganges River Floodplain Soils of Bangladesh
}

\author{
M. H. Rahman ${ }^{1}$, M. M. Farazi ${ }^{2}$, M. A. Rahman ${ }^{3}$, M. M. A. Mamun ${ }^{4}$ and K. Begum \\ ${ }^{1,2 \& 4}$ Central Laboratory, Soil Resource Development Institute, Dhaka-1215; ${ }^{3}$ Upazilla Agriculture \\ Officer, Mirzapur,Tangail; ${ }^{5}$ Lecturer, Soil Science, Dhamrai Government College, Dhaka
}

*Corresponding author and Email: habibso.bd@gmail.com

Received: 18 January 2014 Accepted: 14 June 2014

\begin{abstract}
Bangladesh has been divided into 30 Agro ecological Regions (AEZ). Agricultural research, and technology generation and transfer activities have been carried out on this basis. In context of the lack of enough information on different forms of potassium in the soils of the $30 \mathrm{AEZ}$, an attempt was made to study different forms of potassium of important soils of Bangladesh. As a part of this attempt, an experiment with ten soil samples representing nine different soil series (two of Gopalpur series and one each of Sara, Ishurdi, Ghior, Batra, Sukdebpur, Kumarkhali, Pakuria and Mehendigonj) of the AEZ-12, Low Ganges River Floodplain, was carried out in the Laboratory of the Department of soil science, Bangladesh Agricultural University, Mymensingh to find out the different forms of potassium. The highest value of water soluble potassium $\left(0.08 \mathrm{cmol}(+) \mathrm{K} \mathrm{g}^{-1}\right)$ was obtained in Mehendiganj soil series and the lowest value $\left(0.05 \mathrm{cmol}(+) \mathrm{K} \mathrm{g}^{-1}\right)$ was obtained in Gopalpur-1, 2 and Ishurdi soil series. The highest amount of exchangeable $\mathrm{K}\left(0.29 \mathrm{cmol}(+) \mathrm{K} \mathrm{g}^{-1}\right)$ was found in Batra soil series while the lowest $\left(0.13 \mathrm{cmol}(+) \mathrm{K} \mathrm{g}^{-1}\right)$ in Gopalpur-1 soil series. The highest amount of available $\mathrm{K}(0.35 \mathrm{cmol}$ $\left.(+) \mathrm{K} \mathrm{g}^{-1}\right)$ was found in both Batra and Mehendiganj soil series while the lowest $\left(0.18 \mathrm{cmol}(+) \mathrm{K} \mathrm{g}^{-1}\right)$ in Gopalpur-1 soil series. Considering $0.12 \mathrm{cmol}(+) \mathrm{K} \mathrm{g}^{-1}$ as critical limit (BARC, 2012), all soils had available $\mathrm{K}$ above the critical level. The highest amount of non-exchangeable $\mathrm{K}\left(4.05 \mathrm{cmol}(+) \mathrm{K} \mathrm{g}^{-1}\right)$ was found in Ghior soil series, while the lowest $\left(2.52 \mathrm{cmol}(+) \mathrm{K} \mathrm{g}^{-1}\right)$ was in Mehendiganj soil series.
\end{abstract}

Keywords: Potassium, soils, Bangladesh

\section{Introduction}

Of all the essential elements, potassium is the third most one, after nitrogen and phosphorous, to limit plant growth. For this reason, it is commonly applied to soils as a fertilizer and is a component of most mixed fertilizers. Potassium plays numerous roles in plant and animal nutrition. Potassium is known to activate over 80 different enzymes responsible for plant and animal processes as energy metabolism, starch synthesis, nitrate reduction, photosynthesis and sugar degradation. Potassium is essential for photosynthesis, protein synthesis, nitrogen fixation in legume, starch formation and translocation of sugar. $\mathrm{K}$ is especially important in helping plants adapt to environmental stress. Primary and secondary minerals are the original sources of potassium and are released very slowly by weathering processes.

There are four forms of potassium found in soil namely: a) $\mathrm{K}$ in primary minerals crystal structures, b) $\mathrm{K}$ in non-exchangeable position in 
secondary minerals, c) $\mathrm{K}$ in exchangeable form on soil colloid surfaces, and d) $\mathrm{K}$ ions soluble in water. The total amount of $\mathrm{K}$ in a soil and the distribution of $\mathrm{K}$ among the four major pools are largely a function of the kinds of the clay minerals present in a soil. Generally, soils dominated by $2: 1$ clay contain the most $\mathrm{K}$; those dominated by kaolinite contain the least. $90-98 \%$ of all soil $\mathrm{K}$ in mineral soils is in relatively unavailable forms. The compounds containing most of this form of $\mathrm{K}$ are the micas and feldspars. Only $1-2 \%$ of the total soil $\mathrm{K}$ is readily available. Available $\mathrm{K}$ exists in soil in 2 forms: 1) in the soil solution, and 2) exchangeable $\mathrm{K}$ adsorbed on the colloidal surface.

Bangladesh has been divided into 30 Agroecological Regions (popularly known as AEZs) based on physiography, inundation, land types, soils, and agro-climate (FAO-UNDP, 1988; Islam et al., 2003). Agricultural research, and technology generation and transfer etc. are done on the AEZ basis. Different forms of potassium study emphasizing the AEZs of Bangladesh has not been carried out, although it is very important to have an idea on physico-chemical properties, nutrient behavior as well as inherent potentiality of soils. Considering the above, an attempt has been made to study different forms of potassium of important soils from all AEZs of Bangladesh. As a part of this activity, the Low Ganges River Floodplain, the twelfth AEZ of Bangladesh is reported in the current paper. It occupies an area of $7,968 \mathrm{~km}^{2}$. It has been developed from the calcareous Ganges River alluvium and comprises $29 \%$ medium highland and $31 \%$ medium lowland. The present study was carried out to clarify the status and different forms of potassium in some soils of the Low Ganges River Floodplain soil.

\section{Materials and Methods}

The experiment was carried out in the Laboratory of the Department of soil science, Bangladesh Agricultural University, Mymensingh to find out the different forms of potassium in the Low Ganges River Floodplain
Soils (AEZ-12). The materials used and the methods followed for carrying out the experiment have been described here.

\subsection{Soil used}

Ten soil samples representing nine different soil series; two of Gopalpur series and one each of Sara, Ishurdi, Ghior, Batra, Sukdebpur, Kumarkhali, Pakuria and Mehendigonj series were selected for the present study from the AEZ-12, Low Ganges River Floodplain Soil. The sampling depth was $0-15 \mathrm{~cm}$ and the samples were collected from the sadar and Sathia upazila of Pabna, Gurudaspur upazila of Natore

Districts. Description of soil series and soil Taxonomy is given in Table1.

\subsection{Preparation of the soil samples}

Collected soil samples were air-dried, ground, and passed through a $2 \mathrm{~mm}$ sieve and preserved in plastic bottles for subsequent analysis. The weeds, stubbles etc. were removed from the samples before grinding.

\subsection{Particle size analysis}

The $<2 \mu \mathrm{m}$ clay fraction was separated by repeated stirring-sedimentation-siphoning. The 2-20 $\mu \mathrm{m}$ fraction was separated by repeated sedimentation and siphoning, and the 20-53, 53212 and 212-2,000 $\mu \mathrm{m}$ fractions were separated by wet-sieving. Weights of each fraction were determined to calculate the particle-size distribution.

\subsection{Soil analysis}

\subsubsection{Soil pH}

To determine soil $\mathrm{pH}$, soil was suspended in water at a ratio of 1:2.5 (Jackson, 1962) i.e. $20 \mathrm{~g}$ of soil sample was taken in a beaker and $50 \mathrm{ml}$ of distilled water was added. The suspension was shaken in an electrical shaker for 30 minutes and $\mathrm{pH}$ was measured by a glass electrode $\mathrm{pH}$ meter.

\subsubsection{Electrical conductivity (EC)}

The electrical conductivity of the soil was measured from 1:5 soil: water suspension using a EC meter as described by Jackson (1962). The results were expressed in $\mathrm{dSm}^{-1}$. 
Table1. Description of the soils

\begin{tabular}{|c|c|c|c|c|c|c|}
\hline $\begin{array}{l}\text { Sample } \\
\text { no. }\end{array}$ & $\begin{array}{c}\text { Soil } \\
\text { series }\end{array}$ & $\begin{array}{l}\text { General soil } \\
\text { type }\end{array}$ & $\begin{array}{l}\text { Land } \\
\text { type }^{1}\end{array}$ & $\begin{array}{l}\text { FAO } \\
\text { soil unit }\end{array}$ & $\begin{array}{l}\text { USDA soil } \\
\text { taxonomy }\end{array}$ & Location \\
\hline 1 & Sara & $\begin{array}{l}\text { Calcareous } \\
\text { Brown } \\
\text { Floodplain soil }\end{array}$ & $\mathrm{H}$ & $\begin{array}{l}\text { Chromi- } \\
\text { Calcari } \\
\text { Gleysols }\end{array}$ & $\begin{array}{l}\text { Aquic } \\
\text { Eutrochrept }\end{array}$ & $\begin{array}{l}\text { Village: Deepchar, Union: } \\
\text { Dogachi, Upazilla: Sadar, } \\
\text { District: Pabna }\end{array}$ \\
\hline 2 & Gopalpur-1 & $\begin{array}{l}\text { Calcareous } \\
\text { Brown } \\
\text { Floodplain soil }\end{array}$ & $\mathrm{H}$ & $\begin{array}{l}\text { Chromi- } \\
\text { Calcari } \\
\text { Gleysols }\end{array}$ & $\begin{array}{l}\text { Aquic } \\
\text { Eutrochrept }\end{array}$ & $\begin{array}{l}\text { Village: Deepchar, Union: } \\
\text { Dogachi, Upazilla: Sadar, } \\
\text { District: Pabna }\end{array}$ \\
\hline 3 & Gopalpur-2 & $\begin{array}{l}\text { Calcareous } \\
\text { Brown } \\
\text { Floodplain soil }\end{array}$ & M H & $\begin{array}{l}\text { Chromi- } \\
\text { Calcari } \\
\text { Gleysols }\end{array}$ & $\begin{array}{l}\text { Aquic } \\
\text { Eutrochrept }\end{array}$ & $\begin{array}{l}\text { Village: Matpur, Union: } \\
\text { Ataikula, Upazilla: Sathia, } \\
\text { District: Pabna }\end{array}$ \\
\hline 4 & Ishurdi & $\begin{array}{l}\text { Calcareous } \\
\text { Dark Grey } \\
\text { Floodplain soil }\end{array}$ & M H & $\begin{array}{l}\text { Chromi- } \\
\text { Calcari } \\
\text { Gleysols }\end{array}$ & $\begin{array}{l}\text { Aeric } \\
\text { Haplaquept }\end{array}$ & $\begin{array}{l}\text { Village: Brihaspatipur, } \\
\text { Union: Vulubaria, Upazilla: } \\
\text { Sathia, District: Pabna }\end{array}$ \\
\hline 5 & Ghior & $\begin{array}{l}\text { Calcareous } \\
\text { Dark Grey } \\
\text { Floodplain soil }\end{array}$ & ML & $\begin{array}{l}\text { Chromi- } \\
\text { Calcari } \\
\text { Gleysols }\end{array}$ & $\begin{array}{l}\text { Aeric } \\
\text { Haplaquept }\end{array}$ & $\begin{array}{l}\text { Village: Shibpur, Union: } \\
\text { Vulubaria, Upazilla: Santhia, } \\
\text { District: Pabna }\end{array}$ \\
\hline 6 & Sukdel & $\begin{array}{l}\text { Calcareous } \\
\text { Brown } \\
\text { Floodplain soil }\end{array}$ & M H & $\begin{array}{l}\text { Chromi- } \\
\text { Calcari } \\
\text { Gleysols }\end{array}$ & $\begin{array}{l}\text { Aquic } \\
\text { Eutrochrept }\end{array}$ & $\begin{array}{l}\text { Village: Voirobpur, Union: } \\
\text { Khetupara, Upazilla: } \\
\text { Santhia, District: Pabna }\end{array}$ \\
\hline 7 & Pakuria & $\begin{array}{l}\text { Calcareous } \\
\text { Dark Grey } \\
\text { Floodplain soil }\end{array}$ & ML & $\begin{array}{l}\text { Chromi- } \\
\text { Calcari } \\
\text { Gleysols }\end{array}$ & $\begin{array}{l}\text { Aeric } \\
\text { Haplaquept }\end{array}$ & $\begin{array}{l}\text { Village: Matpur, Union: } \\
\text { Ataikula, Upazilla: Santhia, } \\
\text { District: Pabna }\end{array}$ \\
\hline 8 & Batra & $\begin{array}{l}\text { Non-calcareous } \\
\text { Dark Grey } \\
\text { Floodplain soil }\end{array}$ & $\mathrm{L}$ & $\begin{array}{l}\text { Vertii- } \\
\text { Eutric } \\
\text { Gleysols }\end{array}$ & $\begin{array}{l}\text { Aeric } \\
\text { Haplaquept }\end{array}$ & $\begin{array}{l}\text { Village: Shibpur, Union: } \\
\text { Vulubaria, Upazilla: Santhia, } \\
\text { District: Pabna }\end{array}$ \\
\hline 9 & Kumarkhali & $\begin{array}{l}\text { Calcareous } \\
\text { Brown } \\
\text { Floodplain soil }\end{array}$ & VL & $\begin{array}{l}\text { Chromi- } \\
\text { Calcari } \\
\text { Gleysols }\end{array}$ & $\begin{array}{l}\text { Aquic } \\
\text { Eutrochrept }\end{array}$ & $\begin{array}{l}\text { Village: Ganghati, Union: } \\
\text { Ataikula, Upazilla: Santhia, } \\
\text { District: Pabna }\end{array}$ \\
\hline 10 & Mehendiganj & $\begin{array}{l}\text { Calcareous } \\
\text { Dark Grey } \\
\text { Floodplain soil } \\
\end{array}$ & VL & $\begin{array}{l}\text { Chromi- } \\
\text { Calcari } \\
\text { Gleysols }\end{array}$ & $\begin{array}{l}\text { Aeric } \\
\text { Haplaquept }\end{array}$ & $\begin{array}{l}\text { Village: Beelbihaspur, Union: } \\
\text { Mosinda, Upazilla: } \\
\text { Gurudaspur, District: Natore }\end{array}$ \\
\hline
\end{tabular}

${ }^{1} \mathrm{H}=$ Highland, $\mathrm{MH}=$ Medium Highland, ML=Medium Lowland, L=Lowland, VL=Very Lowland

2.4.3. Cation exchange capacity (CEC)

Cation exchange capacity of soil was determined by sodium saturation method as outlined by Chapman (1965). The soil samples were saturated with $1 \mathrm{M} \mathrm{CH}_{3} \mathrm{COONa}$ (8.2) was used to replace all the cations from the exchangeable sites. Excess salt was removed by washing with isopropanol. Finally, $\mathrm{Na}$ was brought into solution by exchanging with $1 \mathrm{M} \mathrm{CH} \mathrm{COONH}_{4}$
(pH 7.0) (Chapman, 1965). The Na concentration was measured by Flame Photometer.

\subsubsection{Extractable bases}

To determine $\mathrm{CH}_{3} \mathrm{COONH}_{4}$ extractable $\mathrm{K}$, Ca, $\mathrm{Mg}$ and $\mathrm{Na}$ (Page, 1982), $2.5 \mathrm{~g}$ soil sample was placed in a $15 \mathrm{ml}$ centrifugal tube. About $8 \mathrm{ml}$ of $\mathrm{CH}_{3} \mathrm{COONH}_{4}$ was added the tube was shaken for 
10 minutes. Then the suspension was centrifuged for 5 minutes at $1500 \mathrm{rpm}$ and the supernatant was decanted and filtered into a $25 \mathrm{ml}$ volumetric flask. Extracted $\mathrm{K}, \mathrm{Ca}$ and $\mathrm{Na}$ were determined by Flame Photometer and $\mathrm{Mg}$ by Atomic Absorption Spectrophotometer.

\subsubsection{Water soluble potassium}

Water soluble potassium was determined in 1:5 of soil: water extract by the method adopted by Grewal and Kanwar (1966).

\subsubsection{Exchangeable potassium}

Exchangeable potassium was calculated by subtracting the water soluble $\mathrm{K}$ from that of the available $\mathrm{K}$ extracted by $\mathrm{CH}_{3} \mathrm{COONH}_{4}\left(\mathrm{p}^{\mathrm{H}} 7.0\right)$ (Knudsen et al. 1982).

\subsubsection{Non-exchangeable potassium}

Non-exchangeable potassium was determined according to Knudsen et al. (1982) as: From the finely ground soil sample, $2.5 \mathrm{~g}$ was taken and placed in a $250 \mathrm{ml}$ Erlenmeyer flask, $25 \mathrm{ml}$ of 1 $\mathrm{N} \mathrm{HNO}_{3}$ was added to it, placed on a water bath and was boiled gently for about 15 minutes. After cooling, the liquid portion was poured through Whatman 42 filter paper into $100 \mathrm{ml}$ volumetric flask. The remaining soil was washed with $15 \mathrm{ml}$ portions of $0.1 \mathrm{~N} \mathrm{HNO}_{3}$ for four times. Non-exchangeable $\mathrm{K}$ was obtained by subtracting the available $\mathrm{K}$ (extracted by $\mathrm{CH}_{3} \mathrm{COONH}_{4}$ ) value from the value of total $\mathrm{K}$

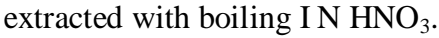

\subsection{Statistical analysis}

Pearson's correlation coefficient (r) was carried out to find out the correlation among different forms of potassium (water soluble, exchangeable, available and non-exchangeable) by SPSS software.

\section{Results and Discussion}

Some selected physical and chemical properties of these soils are presented in Table 2 and 3 . The highest amount of clay $(<2 \mu \mathrm{m})$ was found in soil of Pakuria series $(35.7 \%)$ and the lowest in soil of Sara series (18.6) presented in Table 3.
The clay content showed variation with topography. In general, the soils collected from high land had lower clay content than those collected from lowland. The reason is, high land receives no sediments as their location is above flood level. Moreover, due to surface runoff, the finer particles wash away to the lower eleviation. Egashira and Yasmin (1990) found 22.1 and $48.6 \%$ clay in Ishurdi and Ghior series respectively which support the findings of the present study. According to the USDA system for textural classes, only Ghior series was loam and the rest eight soil series of the present study were silt loam (Table 3). According to the ISSS system, the textural classes of Sara, Gopalpur-1 and Ishurdi series were silty clay loam; Gopalpur-2 and sukdebpur series were clay loam; Ghior series was silty clay and the rest of the series were light clay. Egashira and Yasmin (1990) also found that the USDA textural classes of Ishurdi Ghior soils were similar to the present findings.

Different forms of potassium (water soluble, exchangeable, available, and non-exchangeable) in the soils used in the present study are presented in Table 4. Water soluble potassium obtained from the Low Ganges River Floodplain soil Ranged from 0.05 to $0.08 \mathrm{cmol}^{(+)} \mathrm{K} \mathrm{g}^{-1}$ with an average of $0.06 \mathrm{cmol}(+) \mathrm{K} \mathrm{g} \mathrm{g}^{-1}$.

The highest value $0.08 \mathrm{cmol}(+) \mathrm{K} \mathrm{g}^{-1}$ was found in Mehendiganj soil series. The exchangeable $\mathrm{K}$ of the soils ranged from 0.13 to $0.29 \mathrm{cmol}(+) \mathrm{K}$ $\mathrm{g}^{-1}$. The highest amount of exchangeable K $(0.29$ cmol(+) $\mathrm{K} \mathrm{g}^{-1}$ ) was found in Batra soil series while the lowest $\left(0.13 \operatorname{cmol}(+) \mathrm{K} \mathrm{g}^{-1}\right)$ in Gopalpur-1 soil series. The highest amount of available $\mathrm{K}\left(0.35 \mathrm{cmol}(+) \mathrm{K} \mathrm{g}^{-1}\right)$ was found in both Batra and Mehendiganj soil series while the lowest $\left(0.18 \mathrm{cmol}(+) \mathrm{K} \mathrm{g} \mathrm{g}^{-1}\right)$ in Gopalpur-1 soil series. Moslehuddin and Egashira (1999) found available $\mathrm{K}$ in a range of 0.14 to $0.49 \mathrm{cmol}(+) \mathrm{K}$ $\mathrm{g}^{-1}$ in soils of Ganges Floodplain which agrees with the support to the present findings. Considering $0.12 \mathrm{cmol}^{(+)} \mathrm{K} \mathrm{g}^{-1}$ as critical limit (BARC, 2012), all soils in the present study had available $\mathrm{K}$ above the critical level. 
Table 2. Some selected chemical properties of the soils

\begin{tabular}{|c|c|c|c|c|c|c|c|c|c|}
\hline \multirow[t]{2}{*}{$\begin{array}{l}\text { Sl. } \\
\text { no. }\end{array}$} & \multirow[t]{2}{*}{ Soil series } & \multirow[t]{2}{*}{$\mathrm{pH}$} & \multirow[t]{2}{*}{$\begin{array}{c}\mathrm{EC} \\
\left(\mathrm{dSm}^{-1}\right)\end{array}$} & \multirow[t]{2}{*}{$\begin{array}{c}\mathrm{CEC} \\
\left(\mathrm{cmol}^{+} \mathrm{Kg}^{-1}\right)\end{array}$} & \multicolumn{4}{|c|}{$\begin{array}{c}\text { Exchangeable bases } \\
\left(\mathrm{Cmol}^{+} \mathrm{K} \mathrm{g}^{-1}\right)\end{array}$} & \multirow[t]{2}{*}{$\begin{array}{l}\% \text { of base } \\
\text { saturation }\end{array}$} \\
\hline & & & & & $\mathrm{K}$ & $\mathrm{Ca}$ & $\mathrm{Mg}$ & $\mathrm{Na}$ & \\
\hline 1 & Sara & 7.1 & 0.16 & 18.8 & 0.17 & 10.5 & 5.4 & 0.17 & 86.4 \\
\hline 2 & Gopalpur-1 & 7.3 & 0.21 & 28.4 & 0.13 & 10.6 & 12.2 & 0.33 & 81.9 \\
\hline 3 & Gopalpur-2 & 7.1 & 0.15 & 31.5 & 0.19 & 9.30 & 15.6 & 0.37 & 80.8 \\
\hline 4 & Ishurdi & 7.4 & 0.23 & 36.4 & 0.16 & 11.5 & 15.9 & 0.59 & 78.0 \\
\hline 5 & Ghior & 7.5 & 0.14 & 39.3 & 0.20 & 8.10 & 15.4 & 0.39 & 61.3 \\
\hline 6 & Sukdebpur & 6.7 & 0.14 & 57.6 & 0.20 & 6.50 & 10.1 & 0.33 & 29.7 \\
\hline 7 & Pakuria & 6.9 & 0.26 & 37.0 & 0.22 & 7.60 & 16.5 & 0.57 & 67.3 \\
\hline 8 & Batra & 7.3 & 0.32 & 53.3 & 0.29 & 11.8 & 20.4 & 0.91 & 62.7 \\
\hline 9 & Kumarkhali & 7.3 & 0.32 & 26.9 & 0.21 & 11.3 & 11.4 & 0.43 & 86.8 \\
\hline 10 & Mehendiganj & 7.4 & 0.14 & 35.4 & 0.27 & 12.6 & 13.6 & 0.22 & 75.4 \\
\hline \multicolumn{2}{|c|}{ Average } & 7.2 & 0.21 & 36.73 & 0.18 & 9.95 & 13.65 & 0.43 & 71.03 \\
\hline
\end{tabular}

Table 3. Particle size distribution of soils

\begin{tabular}{|c|c|c|c|c|c|c|c|}
\hline \multirow[t]{2}{*}{ Sl. no. } & \multirow[t]{2}{*}{ Soil series } & \multicolumn{5}{|c|}{ Particle-size Distribution (\%) } & \multirow[b]{2}{*}{$\begin{array}{l}\text { Soil } \\
\text { textural } \\
\text { classes } \\
\text { USDA } \\
\text { system }\end{array}$} \\
\hline & & $\begin{array}{l}<2 \mu \mathrm{m} \\
\text { (clay) }\end{array}$ & $\begin{array}{l}2-20 \\
\mu \mathrm{m} \\
\text { (silt) }\end{array}$ & $\begin{array}{l}20-53 \mu \mathrm{m} \\
\text { (silt in USDA } \\
\text { and fine sand } \\
\text { in ISSS) }\end{array}$ & $\begin{array}{l}53-212 \\
\mu \mathrm{m} \text { (fine } \\
\text { sand in } \\
\text { ISSS) }\end{array}$ & $\begin{array}{l}212-2000 \\
\mu \mathrm{m} \text { (coarse } \\
\text { sand in } \\
\text { ISSS) }\end{array}$ & \\
\hline 1 & Sara & 18.6 & 47.0 & 19.7 & 14.2 & 0.05 & SiL \\
\hline 2 & Gopalpur-1 & 21.1 & 64.4 & 11.7 & 2.7 & 0.1 & SiL \\
\hline 3 & Gopalpur-2 & 21.8 & 36.4 & 14.5 & 26.4 & 0.9 & SiL \\
\hline 4 & Ishurdi & 21.3 & 55.3 & 12.6 & 10.2 & 0.6 & SiL \\
\hline 5 & Ghior & 24.1 & 50.9 & 14.9 & 9.8 & 0.3 & $\mathrm{~L}$ \\
\hline 6 & Sukdebpur & 24.3 & 26.7 & 19.3 & 29.1 & 0.6 & SiL \\
\hline 7 & Pakuria & 35.7 & 36.4 & 14.2 & 13.2 & 0.6 & SiL \\
\hline 8 & Batra & 26.6 & 56.2 & 13.3 & 3.2 & 0.7 & SiL \\
\hline 9 & Kumarkhali & 28.4 & 45.0 & 12.6 & 13.6 & 0.4 & SiL \\
\hline 10 & Mehendiganj & 25.3 & 64.2 & 6.8 & 2.9 & 0.8 & SiL \\
\hline
\end{tabular}

USDA- United States Department of Agriculture, ISSS- International Society of Soil Science $\mathrm{SiL}=$ Silt Loam; $\mathrm{L}=$ Loam

The non-exchangeable $\mathrm{K}$ of the soils in the present study ranged from 2.52 to $4.05 \mathrm{cmol}(+)$ $\mathrm{K} \mathrm{g}^{-1}$. The highest amount of non-exchangeable $\mathrm{K}\left(4.05 \mathrm{cmol}(+) \mathrm{K} \mathrm{g}^{-1}\right)$ was found in Ghior soil series while the lowest $\left(2.52 \mathrm{cmol}^{(+)} \mathrm{K} \mathrm{g}^{-1}\right)$ in Mehendiganj soil series. Vermiculite and smectite minerals are mainly responsible to fix $\mathrm{K}$ as non-exchangeable form. High content of smectite resulted in high status of nonexchangeable $\mathrm{K}$ in these soils. Thus, the impact of mineralogy on non-exchangeable $\mathrm{K}$ content was much prominent in the present study. Nonexchangeable $\mathrm{K}$ fraction is very important in terms of potassium supplying power of the soil. For example, all soils of Ghior, Sukdebpur and Kumarkhali series had same amount of available $\mathrm{K}\left(0.27 \mathrm{cmol}(+) \mathrm{K} \mathrm{g}^{-1}\right)$ but $4.05,3.30$ and 2.80 cmol (+) $\mathrm{K} \mathrm{g}^{-1}$ non-exchangeable $\mathrm{K}$ implying different levels of $\mathrm{K}$ supplying capacity during crop production. It indicates that there is no relationship between available and nonexchangeable $\mathrm{K}$. 
Shapley (1989) also found that determination of both exchangeable and $\mathrm{HNO}_{3}$ - extractable $\mathrm{K}$ gave a better indication of the potential $\mathrm{K}$ supplying capacity of the soils from a study with 102 soils of 10 orders.
The correlation coefficients (r) among different forms of potassium (water soluble, exchangeable, available and non-exchangeable) in the Low Ganges River Floodplain soil as shown in Table 5.

Table 4. Different forms of potassium in experimental soils

\begin{tabular}{|c|c|c|c|c|c|c|c|}
\hline \multirow{2}{*}{$\begin{array}{l}\text { Sl. } \\
\text { no. }\end{array}$} & \multirow{2}{*}{$\begin{array}{c}\text { Soil } \\
\text { series }\end{array}$} & \multicolumn{6}{|c|}{ Forms of soil $\mathrm{K} \mathrm{cmol}(+) \mathrm{Kg}^{-1}$} \\
\hline & & $\begin{array}{c}\text { Water } \\
\text { soluble K }\end{array}$ & $\begin{array}{c}\% \text { of } \\
\text { available K }\end{array}$ & $\begin{array}{c}\text { Exchangeable } \\
\text { K }\end{array}$ & $\begin{array}{c}\% \text { of } \\
\text { available } \mathrm{K}\end{array}$ & $\begin{array}{c}\text { Available } \\
\mathrm{K}\end{array}$ & $\begin{array}{c}\text { Non- } \\
\text { exchangeable } \\
\mathrm{K}\end{array}$ \\
\hline 1 & Sara & 0.06 & 26 & 0.17 & 74 & 0.23 & 3.38 \\
\hline 2 & Gopalpur-1 & 0.05 & 28 & 0.13 & 72 & 0.18 & 2.62 \\
\hline 3 & Gopalpur-2 & 0.05 & 21 & 0.19 & 79 & 0.24 & 3.00 \\
\hline 4 & Ishurdi & 0.05 & 24 & 0.16 & 76 & 0.21 & 3.99 \\
\hline 5 & Ghior & 0.07 & 26 & 0.20 & 74 & 0.27 & 4.05 \\
\hline 6 & Sukdebpur & 0.07 & 26 & 0.20 & 74 & 0.27 & 3.30 \\
\hline 7 & Pakuria & 0.06 & 21 & 0.22 & 79 & 0.28 & 3.10 \\
\hline 8 & Batra & 0.06 & 17 & 0.29 & 83 & 0.35 & 3.20 \\
\hline 9 & Kumarkhali & 0.06 & 22 & 0.21 & 78 & 0.27 & 2.80 \\
\hline 10 & Mehendiganj & 0.08 & 23 & 0.27 & 77 & 0.35 & 2.52 \\
\hline \multicolumn{2}{|c|}{ Average } & 0.06 & 23 & 0.20 & 77 & 0.27 & 3.20 \\
\hline \multicolumn{2}{|c|}{ Maximum } & 0.08 & 28 & 0.29 & 83 & 0.35 & 4.05 \\
\hline \multicolumn{2}{|c|}{ Minimum } & 0.05 & 17 & 0.13 & 72 & 0.18 & 2.52 \\
\hline \multicolumn{2}{|c|}{ Standard Deviation } & 0.01 & 0.09 & 0.05 & 11.29 & 0.05 & 0.52 \\
\hline
\end{tabular}

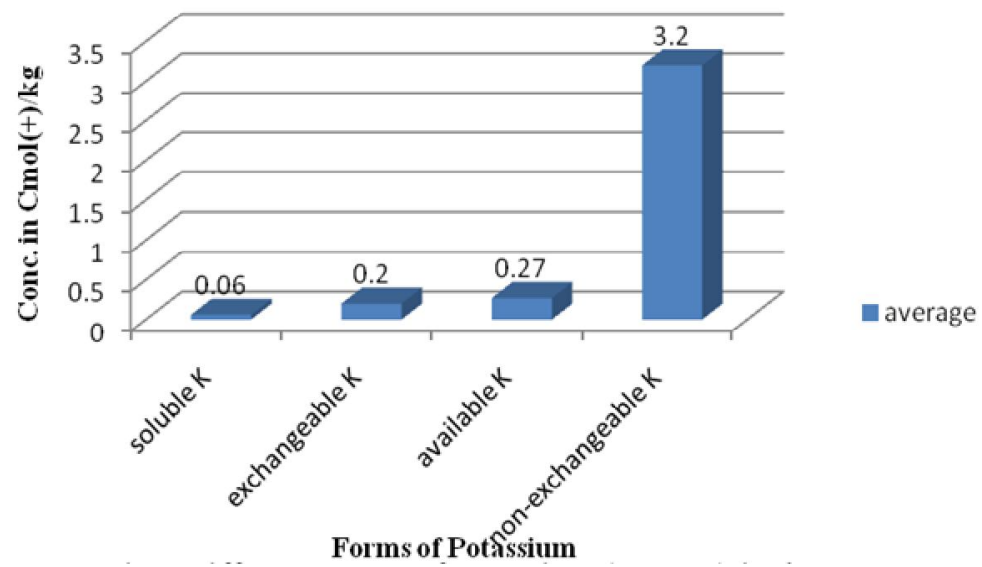

Fig. 1. Different forms of potassium (average) in the experimental soils 
Table 5. Correlation coefficients (r) among different forms of potassium (water soluble, exchangeable, available and non-exchangeable) in the Low Ganges River Floodplain Soil

\begin{tabular}{lcccc}
\hline & $\begin{array}{c}\text { Water soluble } \\
(\mathrm{K})\end{array}$ & $\begin{array}{c}\text { Exchangeable } \\
(\mathrm{K})\end{array}$ & $\begin{array}{c}\text { Available } \\
(\mathrm{K})\end{array}$ & $\begin{array}{c}\text { Non-exchangeable } \\
(\mathrm{K})\end{array}$ \\
\hline Water soluble K & 1.000 & & & \\
Exchangeable K & 0.594 & 1.000 & & \\
Available K & $0.706^{*}$ & $0.989^{* *}$ & 1.000 & \\
Non-exchangeable K & -0.094 & -0.214 & -0.205 & 1.000 \\
\hline
\end{tabular}

*Correlation is significant at the 0.05 level (1-Tailed)

**Correlation is significant at the 0.01 level (1-Tailed)

It is interesting to note that the water soluble form of $\mathrm{K}$ was significantly correlated with the available form of $\mathrm{K}(\mathrm{r}=0.706)$. This clearly indicates that the increase of water soluble form of $\mathrm{K}$ in the study area have increased the available form of $\mathrm{K}$. Highly significant correlation was obtained between exchangeable and available form of $\mathrm{K}(\mathrm{r}=0.989)$. Both water soluble and exchangeable form of $\mathrm{K}$ were significantly correlated with the available form of $\mathrm{K}$, because available form of $\mathrm{K}$ is the sum of water soluble and exchangeable form of K. Nonsignificant but positive correlation between the water soluble and exchangeable form of $\mathrm{K}$ $(r=0.594)$ was observed. Non-significant but negative correlation was obtained among the water soluble, exchangeable available and nonexchangeable form of $\mathrm{K}$.

\section{Conclusions}

Considerable amount of water soluble and exchangeable $\mathrm{K}$ was found in ranges from 0.05 to 0.08 and 0.13 to $0.29 \mathrm{cmol}^{(+)} \mathrm{K} \mathrm{g} \mathrm{g}^{-1}$, respectively in the present study. The available $\mathrm{K}$ ranged from $0.18 \mathrm{cmol}(+) \mathrm{K} \mathrm{g}^{-1}$ in Gopalpur-1 series to $0.35 \mathrm{cmol}(+) \mathrm{K} \mathrm{g}^{-1}$ was found in both Batra and Mehendiganj series. The status of available $\mathrm{K}$ in the present study was medium according to the classification given by BARC. The highest amount of non-exchangeable $\mathrm{K}$ $\left(4.05 \mathrm{cmol}(+) \mathrm{K} \mathrm{g} \mathrm{g}^{-1}\right)$ was found in Ghior soil series while the lowest $\left(2.52 \mathrm{cmol}(+) \mathrm{K} \mathrm{g}^{-1}\right)$ was in Mehendiganj soil series. From the above discussion it is clear that the concentration of different form of $\mathrm{K}$ in soil vary with clay contents as its mineralogical makeup. Therefore, the idea of management of $\mathrm{K}$ can be taken from the mineralogical composition of that soil.

\section{Acknowledgements}

We are grateful to Mr. Ameer Mohammad Zahid, Scientific Officer, and all other staffs of Soil Resource Development Institute, Pabna, for their sincere cooperation and assistance in collecting the soil samples for this study.

\section{References}

BARC, 2012. Fertilizer Recommendation Guide. 2012. Bangladesh Agricultural Research Council, Farmgate, Dhaka, 274 pp.

Chapman, H. D. 1965. Cation Exchange Capacity. In: Methods of Soil Analysis, (ed.), C.A. Black, American Society of Agronomy, Madison, Wisconsin, 891-901 pp.

Egashira, K. and Yasmin, M. 1990. Clay Mineral Composition of Floodplain Soil of Bangladesh is Relation to Physiographic Units. Bulletin of the Institution of Tropical Agriculture. Kyushu University, 13:105-126.

FAO-UNDP, 1988. Land Resources Appraisal of Bangladesh for Agricultural Development. Report 2. Regions of Bangladesh. FAO, Rome, 570 pp. 
Grewal, J. S and Kanwar, J. S. 1966. Forms of Potassium in Panjab Soils. Indian journal of Soil Science, 14:63-67.

Islam, M. N., Mosleuddin, A. Z. M., Hoque, A. K. M. M., Ahmed, I. U. and Egashira, K. 2003. Mineralogy of soils from different agro ecological regions of Bangladesh: Region 1- Old Himalayan Piedmont Plain, Clay Science, 12(3): 131-137.

Jackson, M. L. 1962. Soil Chemical Analysis. Prentice Hall Inc. Eglewood Chiffs, New York, USA. 498 pp.

Knudsen, D., G.A. Peterson and P. F. Pratt. 1982. Lithium, Sodium and Potassium. In
Methods of Soil Analysis, Part 2 ( $2^{\text {nd }}$ edition). 199-224 pp.

Mosleuddin, A. Z. M., and Egashira, K. 1999. Potassium chemistry in some important paddy soils of Bangladesh. Communication in Soil Science and Plant Analysis, 30(3-4): 329-344.

Page, A. L. (ed.). 1982. Methods of Soil Analysis. Part-2 ( $2^{\text {nd }}$ edition). American Society of Agronomy, Wisconsin, USA.

Sharpley, A.N. 1989. Relationship between soil potassium forms and mineralogy. American Journal of Soil Science, 149(1): 1023-1028. 